\title{
PRELIMINARY OBSERVATIONS ON THE SEMINAL CHARACTERISTICS OF RABBITS RAISED IN TWO LOCATIONS IN SOUTHEASTERN NIGERIA.
}

\author{
U. HERBERT, and C.O. ACHA \\ Department of Animal Production, Federal University of Technology, Owerni, Nigeria.
}

Received 21 September, 1994; Accepted 6 June, 1995

\section{ABSTRACT}

A total of sixteen rabbits sourced from two locations in Southeastern Nigeria were used for this study. Semen was collected from all the rabbits twice weekly for eight weeks using an artificial vagina while observation on the effect of time of collection on semen quality were also made. The results obtained indicated that time of collection had no significant effect $(P>0.05)$ on all the seminal characteristics measured. However, source of the animals showed significant effect $(P<0.05)$ on semen volume, sperm concentration, total sperm per ejaculate and proportion of abnormal sperm. Average semen volume, sperm concentration and total sperm per ejaculate were: $0.69 \pm 0.007 \mathrm{ml}$, $104.0 \pm 1.44 \times 10^{6} / \mathrm{ml}$ and $71.40 \pm 0.90 \times 10^{6}$ respectively for the rabbits sourced from Port Harcourt. The corresponding values for rabbits sourced from Owerri were: $0.66 \pm 0.008 \mathrm{ml}, \quad 96.02 \pm 1.63 \times 10^{6} / \mathrm{ml}$ and $63.49 \pm 1.50 \times 10^{6}$ respectively. Abnormal sperm proportions were $11.05 \pm 0.22 \%$ and $12.16 \pm 0.52 \%$ for the rabbits sourced from Port Harcourt and Owerri respectively. There were no significant $(P>0.05)$ differences observed between locations in live sperm concentration and sperm motility. Live sperm concentration and sperm motility were $87.75 \pm 1.09 \%$ and $\mathbf{7 1 . 6 2} \pm \mathbf{0 . 7 4 \%}$ for the Port Harcourt group, while the values obtained for the Owerri group were $88.06 \pm 0.54 \%$ and $71.19 \pm 0.89 \%$ respectively.

KEYWORDS: Rabbits, Seminal Characteristics, Location.

\section{INTRODUCTION}

Research attention is increasingly being focussed on small unconventional and unexploited animal species as meat sources to meet the shortfall in animal protein supply in the less developed countries of the tropics and sub-tropics (Vietmayer, 1985; Cheeke, 1986; Preston and Leng, 1989). In this regard, rabbits are gaining recognition (Owen, 1981; Lebas et al; 1986). Apart from meat, skin and fur are by-products from rabbits which could be used for leather and clothing manufacture (Rougeot, 1986). Rabbit production is limited more by the unavailability of good genetic material for multiplication of high-producing animals through natural or artificial breeding than by nutrition. Incessant and unplanned breeding, inadequate knowledge of the reproductive potentials of breeding animals, as well as poor management of young rabbits to be used as breeding bucks and does at maturity, among other factors, have led to poor production results experienced.

The assessment of the seminal characteristics of rabbits gives an indication of the reproductive potentials of the animals. There is paucity of information on the seminal characteristics of rabbits in the tropics. Hafez (1970) reported seminal characteristics of a medium-sized breed of rabbit to be as follows:- volume of ejaculate, $0.8 \mathrm{ml}$; concentration of sperm, $(10-1000) \times 10^{6} / \mathrm{ml}$; number of sperm per ejaculate, $200 \times 10^{6}$. However, Herbert and Adejumo (1993), working with New Zealand $x$ Dutch - type rabbits in Ibadan obtained the following values: Semen volume $0.71 \pm 0.02 \mathrm{ml}$ (mean \pm S.E); sperm concentration, $110.5 \pm 5.3$ x $10 \%$ ml; total sperm per ejaculate, $77.7 \pm 1.8 \times$ $10^{6}$; sperm motility, $67.50 \pm 1.33 \%$.

The present study was carried out to generate baseline data on the seminal characteristics of rabbit bucks raised in the area and used for breeding purposes. 


\section{MATERIALS AND METHODS}

Sixteen rabbit bucks weighing between 1.8 and $2.4 \mathrm{~kg}$ and aged between 10 and 12 months were used in the experiment. The animals were $\mathrm{F} 1$ crosses between the New Zealand White and the Chinchilla breeds. Eight of the rabbits were obtained from a reputable farm in Port Harcourt, while the other eight were sourced from the Research farm of the Federal University of Technology, Owerri, Nigeria where the experiment was conducted, between May and July 1993. The animals were individually housed in metal cages with wire mesh floors. Cool clean water and a commercial concentrate feed were served to appetite. The feed was supplemented by serving about $100 \mathrm{~g}$ of wilted Panicum maximum to each rabbit daily.

The first two weeks were used to train the animals on the semen collection technique using an artificial vagina designed and described by Herbert (1992) and Herbert and Adejumo (1993) and adjust the animals sourced from Port Harcourt to their new immediate surroundings. Semen collection was made over the next 8 weeks by ejaculating the animals twice weekly, with alternations between morning $(8.00 \mathrm{am})$ and afternoon $(3.00 \mathrm{pm})$ every other week. A non-gravid mature doe was used as a teaser to stimulate bucks.

Freshly collected semen samples were promptly analysed as follows: Semen volume was read off the collection tube. Sperm concentration was determined on diluted semen using the hemocytometer counts. The number of spermatozoa per ejaculate was determined by multiplying the semen volume by the sperm concentration. Progressive sperm motility was determined after dilution in normal saline at $37^{\circ} \mathrm{C}$. Abnormal sperm frequencies were determined on semen samples after staining with methylene violet, while live sperm concentration was determined after differential staining in $1 \%$ eosin and $4 \%$ aniline blue.

Data collected were subjected to analysin of variance (Steel and Torrie, 1980) to determine differences between the groups of animals. Simple correlations were also used to evaluate the relationships between some of the parameters measured.

\section{RESULTS}

Table 1 shows the mean values and standard errors of the seminal characteristics of rabbits from the two locations by the time of collection. Time of collection did not significantly affect $(P>0.05)$ any of the parameters measured. Table 2 shows the overall results of the seminal characteristics for the two locations irrespective of time of collection.

Semen volume, sperm concentration and total sperm per ejaculate were significantly $(P<0.05)$ higher for the animals that were sourced from Port Harcourt than their Owerri counterparts. On the other hand, abnormal sperm proportion was significantly $(\mathbf{P}<0.05)$ higher for the Owerri-bred animals than their Port Harcourt counterparts. Live sperm concentration and progressive motility did not significantly $(\mathrm{P}>0.05)$ differ between the two groups. In both groups of animals, number of sperm per ejaculate correlated positively and significantly with sperm concentration as well as semen volume (Table 3 ). Live sperm concentration correlated positively with semen volume and number of sperm per ejaculate.

\section{DISCUSSION}

The time of collection was found to have no effect on the seminal characteristics. It is possible that the good housing provided with ample ventilation may have prevented any deleterious effects on semen harvested in the afternoons. The secretory abilities of the accessory sex glands provide the major influence on the volume of semen as demonstrated by the large ejaculates from the boar and horse which have well developed secretory glands (Edwards, 1968). The mean volumes of semen recorded in this study are comparable to those reported by Hafez (1970) and Herbert and Adejumo (1993) for medium-sized breeds of rabbits. The sperm concentrations observed here fall within the 
SEMINAL CHARACTERISTICS OF RABBITS

TABLE 1: MEAN VALUES OF SEMINAL CHARACTERISTICS OF RABBITS AT DIFFERENT COLLCTION TIMES IN THE TWO LOCATIONS (MEAN \pm SEM)

\begin{tabular}{|c|c|c|c|c|}
\hline $\begin{array}{l}\text { Semen } \\
\text { Trait }\end{array}$ & $\begin{array}{l}\text { Port Harcourt } \\
\text { Collection Time } \\
\text { Morning }\end{array}$ & Aftemoon & $\begin{array}{l}\text { Owerri } \\
\text { Collection Time } \\
\text { Morning }\end{array}$ & Afternoon \\
\hline \multirow{5}{*}{$\begin{array}{l}\text { Semen } \\
\text { Volume (ml) } \\
\text { Sperm } \\
\text { Concentration } \\
\left.\text { (x } 10^{6} / \mathrm{ml}\right) \\
\text { Total Sperm } \\
\text { per ejaculate } \\
\text { (xi0) } \\
\text { Live sperm (\%) } \\
\text { Abnormal } \\
\text { sperm (\%) } \\
\text { Progressive } \\
\text { motility (\%) }\end{array}$} & $0.69 \pm 0.009$ & $0.68 \pm 0.008$ & $0.66 \pm 0.009$ & $0.65 \pm 0.009$ \\
\hline & $105.4 \pm 1.67$ & $1025 \pm 1.34$ & $96.38 \pm 1.83$ & $95.25 \pm 1.80$ \\
\hline & $\begin{array}{l}72.33 \pm 1.32 \\
88.00 \pm 1.36\end{array}$ & $\begin{array}{l}70.46 \pm 0.82 \\
87.50 \pm 0.89\end{array}$ & $\begin{array}{l}64.20 \pm 1.81 \\
88.12 \pm 0.72\end{array}$ & $\begin{array}{l}62.77 \pm 1.57 \\
88.00 \pm 0.71\end{array}$ \\
\hline & $11.06 \pm 0.45$ & $11 . \pm 0.30$ & $12.2 \pm 0.68$ & $12.11 \pm 0.45$ \\
\hline & $71.62 \pm 0.86$ & $71.62 \pm 0.88$ & $70.37 \pm 0.86$ & $72.0 \pm 1.00$ \\
\hline
\end{tabular}

TABLE 2: SEMINAL CHAFACTERISTICS OF RABBIT RAISED AT TWO LOCATIONS IN SOUTH-EASTERN NIGERIA.

\begin{tabular}{lll}
\hline Semen Trait & $\begin{array}{l}\text { Portharcourt } \\
\text { (mean } \pm \text { S.E.) }\end{array}$ & $\begin{array}{c}\text { Location } \\
\text { Owerri } \\
\text { (mean } \pm \text { S.E.) }\end{array}$ \\
\hline Semen volume $(\mathrm{ml})$ & $0.69 \pm 0.007^{\mathrm{*}}$ & $0.66 \pm 0.008^{\mathrm{b}}$ \\
Sperm concentration $\left(\times 10^{6} / \mathrm{ml}\right)$ & $104.0 \pm 1.44^{\mathrm{a}}$ & $96.02 \pm 1.36^{\mathrm{b}}$ \\
Total sperm per cjaculate $\left(\times 10^{6}\right)$ & $71.40 \pm 0.90^{\mathrm{a}}$ & $63.49 \pm 1.50^{\mathrm{b}}$ \\
Live sperm $(\%)$ & $87.75 \pm 1.09^{\mathrm{a}}$ & $88.06 \pm 0.54^{\mathrm{a}}$ \\
Abnormal sperm $(\%)$ & $11.05 \pm 0.22^{\mathrm{b}}$ & $12.16 \pm 0.52^{\mathrm{a}}$ \\
Progressive motility $(\%)$ & $71.62 \pm 0.74^{\mathrm{a}}$ & $71.19 \pm 0.89^{\mathrm{a}}$ \\
\hline
\end{tabular}

ab. Means on the same now having different superscripts are significantly different from one another $(\mathrm{P}<0.05)$.

TABLE 3: SIMPLE CORRELATIONS BETWEEN SEMINAL CHARACTERISTICS OF THE EXPERIMENTAL ANIMALS BY SOURCE OF ANIMALS.

\begin{tabular}{|c|c|c|c|c|c|}
\hline & CONC. & VOL. & EJA. & MOT. & LIVE \\
\hline \multicolumn{6}{|c|}{ PORT HARCOURT } \\
\hline Vol. & $0.49^{*}$ & & & & \\
\hline Eja. & $0.74^{* *}$ & $0.63^{*}$ & & & \\
\hline $\begin{array}{l}\text { Mot. } \\
\text { Live }\end{array}$ & 0.26 & $0.34^{*}$ & 0.03 & & \\
\hline Live & $0.19^{*}$ & $0.41^{*}$ & $0.53^{*}$ & 0.34 & \\
\hline Abno. & 0.02 & 0.33 & -0.22 & $0.67^{*}$ & -0.03 \\
\hline \multicolumn{6}{|c|}{ OWERRI } \\
\hline $\begin{array}{l}\text { Vol. } \\
\text { Eja. }\end{array}$ & 0.35 & & & & \\
\hline $\begin{array}{l}\text { Eja. } \\
\text { Mot. }\end{array}$ & $0.89^{* *}$ & $0.74^{* * *}$ & & & \\
\hline $\begin{array}{l}\text { Mot. } \\
\text { Live }\end{array}$ & 0.34 & $0.55^{*}$ & 0.14 & & \\
\hline $\begin{array}{l}\text { Live } \\
\text { Abno. }\end{array}$ & $0.56^{*}$ & $0.63^{*}$ & $0.71^{* *}$ & 0.14 & \\
\hline Abno. & 0.02 & 0.05 & 0.04 & 0.00 & -0.01 \\
\hline
\end{tabular}

$\begin{array}{lll}\text { CONC } & = & \text { Concentration/ml } \\ \text { EJA } & = & \text { Sp. Concentration/ejaculate } \\ \text { UVE } & = & \text { Live sperm }(\%) \\ \text { VOL } & = & \text { P }<0.05 \% \\ \text { Ejoculate volume }(\mathrm{ml}) \\ \text { MOT } & = & \text { Prot motility }(\%) \\ \text { ABNO } & = & \text { Abnormal sperm }(\%)\end{array}$


$100-1000 \times 10^{6} / \mathrm{ml}$ reported by Hafez (1970) but were lower than $219 \times 10^{6} / \mathrm{ml}$ reported by Amann (1966). The mean numbers of sperm per ejaculate were lower than values reported elsewhere (Desjardins et al., 1968; Hafez, 1970 and Herbert and Adejumo, 1993). The animals sourced from Port Harcourt produced higher sperm counts than those raised at Owerri. Sperm production is the primary function of the testis. A positive relationship has been established between sperm output and testis weight (Edwards, 1968; Foote, 1984; Herbert and Adejumo, 1993) which has been linked with genetic differences as well as pre and postnatal development and growth. McDonald et al. (1981) reported that nutritional and management conditions to which animal is subjected during the formative stages of gestation and during postnatal growth affect its performance in later life.

A probe into the management systems under which the two groups of animals were raised revealed that while both groups were intensively produced, the animals in the Port Harcourt group received better attention in terms of nutrition and disease prevention during growth than their Owerri counterparts. Although the animals were recorded to be $F_{1}$ crosses between the New Zealand White and the Chinchilla, it is possible that the parents of the animals in the Owerri group were not purebred New Zealand White which factor may have depressed their performance. Since a higher rate of fertilization is expected from animals with higher rates of sperm output, it follows that source of breeding animals has to be taken into account while selecting breeding bucks with due consideration given to the breeding programme and management practices which may influence the animals' reproductive potentials.

Although live sperm proportion was similar $(P>0.05)$ between the two groups, the incidence of abnormal spermatozoa was higher $(P<0.05)$ for the animals raised in Owerri than those raised in Port Harcourt. Abnormalities could result from deformities or accidents, while radiations could cause both deformities and dead cells. However, abnormalities may also occur as artefacts caused by the staining procedure. In this study, however, the abnormal sperm proportion was much lower than the value of 75\% given by Emele (1991) at which a threat is posed to fertility. In addition, there was no significant relationship between sperm concentration and the proportion of abnormal sperm. Progressive motility was similar between the two groups, and the values obtained are comparable to those of Gregoire et al., (1958) and Herbert and Adejumo (1993).

The results obtained indicate that the animals used in this study have varied reproductive potentials. It is either that the animals raised in Port Harcourt had higher proportions of the genetic constitution of the superior New Zealand White or the animals were managed better during growth.

\section{REFERENCES}

AMANN, R.P. (1966). Effects of ejaculation frequency and brecd on semen characteristics and sperm output of rabbits. J. Reprod. Fertil. 11:291-293.

CHEEKE, P.R. (1986). Potentials of rabbit production in tropical and sub-tropical systems. J. Anim. Sci. 63:1581-1586.

DESJARDINS, C., KIRTON, K.T. and HAFS, H.D. (1968). Sperm output of rabbits at various ejaculation frequencies and their use in the design of experiments. J. Reprod. Fetil. 15:27-32.

EDWARDS, J. (1968). Organs of reproduction. In: The artificial insemination of farm animals, Perry, J.E. (ed.), 4th Ed. Rutgers Univ. Press, New Brunswick and New Jersey. PP. 13-32.

EMELE, J. (1991). Semen characteristics and conception in humans. Bright $\mathrm{Co}$. Inc. New York.

FOOTE, R.H. (1974). In: Reproduction in farm Animals, Hafez, E.S.E. (ed.), Lea and Febiger, Philadelphia PP. 409-431. 
GREGOIRE, A.T., BRATTON, R.W. and FOOTE, R.H. (1958). Sperm output of rabbits ejaculated either once a week or once a day for 43 days. J. Anim. Sci. 17:243-248.

HAFEZ, E.S.E. (1970). Rabbits. In : Reproduction and breeding techniques for laboratory animals, Hafez, E.S.E. (ed) Lea and Febiger, Philadelphia. pp 273-298.

HERBERT, U. (1992). Growth and reproductive characteristics of rabbits fed on Leucaena (Leucaena leucocephala lam) and Gliricidia (Gliricidia sepium, Jacq) foliage. Ph.D. Thesis, University of Ibadan, Nigeria. 374p.

HERBERT, U, and ADEJUMO, D.O. (1993). An artificial vagina for collecting rabbit semen in the tropics. Paper presented at the 18th Annual Conf. Nig. Soc. Anim. Prod., Fed. Univ. of Technol, Owerri, Nigeria, March 21-25, 1993. (Abstr.)

LEBAS, F. , COUDERT, $P$,, ROUVIER, R. and de ROCHAMBEAU, H. (1986). The Rabbit: Husbandry, health and production, FAO Animal Production and Health Series No. 21, Rome. 235p.
McDONALD, $P$, EDWARDS, RA. and GREENHALGH, J.F.D. (1981). Animal Nutrition. 3rd ed. ELBS and Longman, Essex.

OWEN, J.E. (1981). Rabbit meat for the developing countries. Wld. Anim. Rev. 39:2-11.

PRESTON, T.R. and LENG, R.A. (1989). The greenhouse effect and its implications for world agriculture: The need for environmentally friendly development. Livest. Res. for Rural Dev. 1:23-30.

ROUGEOT, J. (1986). Production and marketing of rabbit skin. Wld. Rev. Anim. Prod. 60:7-17.

STEEL, R.G.D. and TORRIE, J.H. (1980). Statistical methods. 2nd ed. McGraw Hill, New York. 633p.

VIETMAYER, N.D. (1985). Potentials of micro-livestock in developing countries. J. Appl. Rabbit. Res. 8:10. 